\title{
(8) pnmbalina
}

\section{Aesthetic damage vs. cosmetic surgery implications in civil law evaluation}

\author{
Autor(es): \\ Carreira, C.; Coelho, A. S.; Sanches, R.; Costa, G. Santos; Corte-Real, \\ F. \\ Publicado por: Imprensa da Universidade de Coimbra; International Academy of Legal \\ Medicine \\ URL \\ persistente: \\ URI:http://hdl.handle.net/10316.2/31868 \\ DOI: \\ DOI:http://dx.doi.org/10.14195/978-989-26-0173-1_61
}

Accessed : $\quad$ 26-Apr-2023 01:39:03

A navegação consulta e descarregamento dos títulos inseridos nas Bibliotecas Digitais UC Digitalis, UC Pombalina e UC Impactum, pressupõem a aceitação plena e sem reservas dos Termos e Condições de Uso destas Bibliotecas Digitais, disponíveis em https://digitalis.uc.pt/pt-pt/termos.

Conforme exposto nos referidos Termos e Condições de Uso, o descarregamento de títulos de acesso restrito requer uma licença válida de autorização devendo o utilizador aceder ao(s) documento(s) a partir de um endereço de IP da instituição detentora da supramencionada licença.

Ao utilizador é apenas permitido o descarregamento para uso pessoal, pelo que o emprego do(s) título(s) descarregado(s) para outro fim, designadamente comercial, carece de autorização do respetivo autor ou editor da obra.

Na medida em que todas as obras da UC Digitalis se encontram protegidas pelo Código do Direito de Autor e Direitos Conexos e demais legislação aplicável, toda a cópia, parcial ou total, deste documento, nos casos em que é legalmente admitida, deverá conter ou fazer-se acompanhar por este aviso.

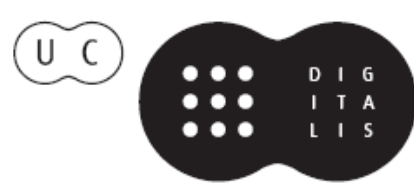




\section{Duarte Nuno Vieira Anthony Busuttil \\ Denis Cusack • Philip Beth}
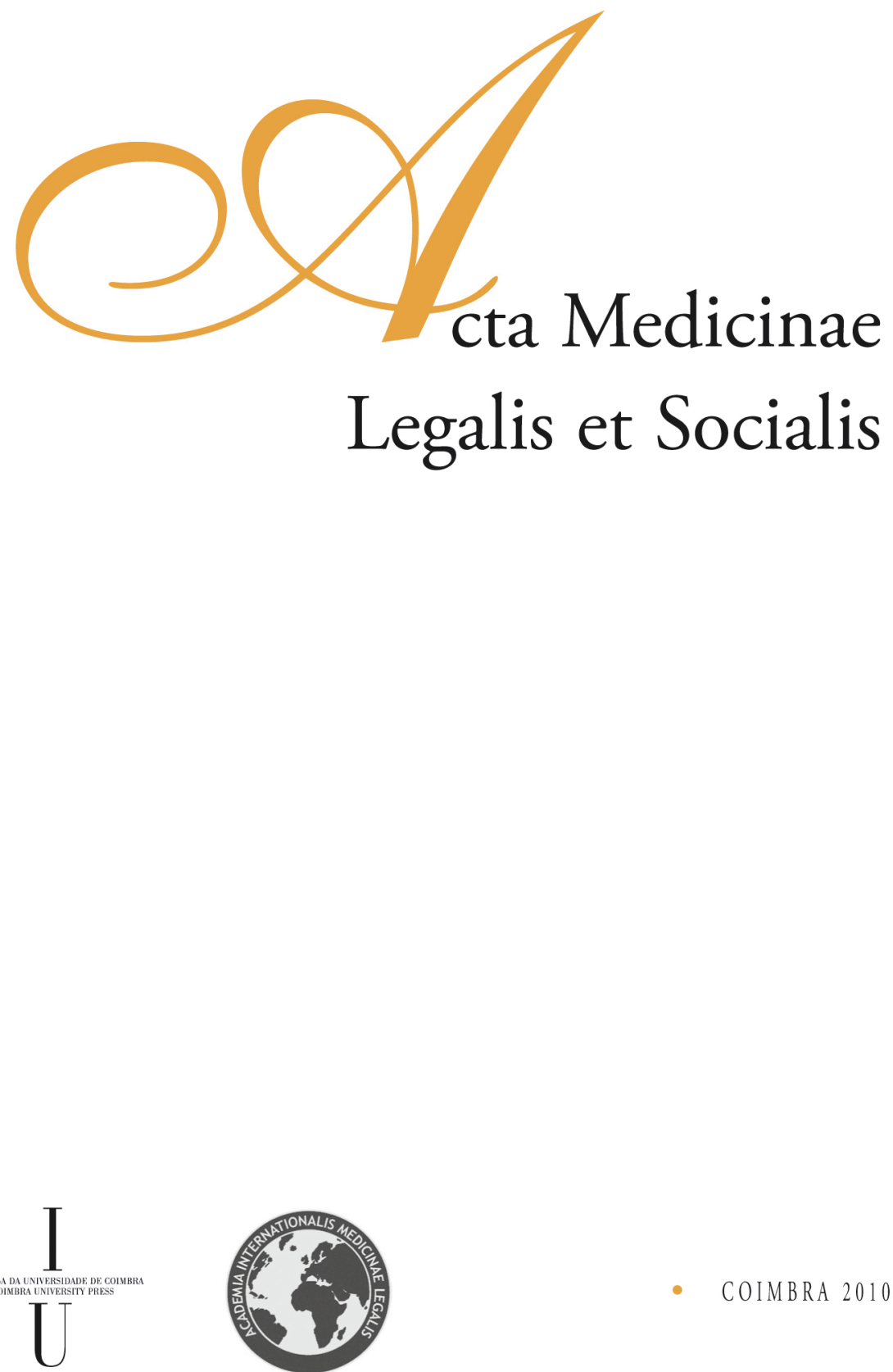


\author{
C. Carreira ${ }^{1,2}$, A. S. Coelho ${ }^{1}$, R. Sanches ${ }^{1}$, G. Santos Costa ${ }^{1}$, F. Corte-Real ${ }^{1,2}$ \\ ${ }^{1}$ Centre Branch of the National Institute of Legal Medicine, Coimbra, Portugal \\ ${ }^{2}$ Faculty of Medicine, University of Coimbra, Portugal
}

\title{
AESTHETIC DAMAGE VS. COSMETIC SURGERY IMPLICATIONS IN CIVIL LAW EVALUATION
}

\begin{abstract}
Taking as an example the case study presented in this paper, we intend to discuss whether the availability of plastic surgery, as a form of improvement of traumatic lesions, should be taken into account during clinical assessment of aesthetic damage, or whether each patient is entitled to refuse this specific therapeutic, considering the risks it involves, like any other form of treatment.
\end{abstract}

\section{Introduction and objectives}

Nowadays, society is consumed by stereotyped images that media, with the help of numerous advertising and marketing campaigns, diffuse all around the world. As a result, appearance has actually become vital to its individuals that are devoured by the need of compulsive consumption in order to correspond to those creations and please others.

Hence, it is not at all surprising, that aesthetic damage is considered susceptible of monetary compensation following trauma in civil responsibility cases.

Medical experts are thus, expected to be familiar with this field so as to produce precise clinical evaluation that will be the foundation on which the judge can determine each individual compensation.

In the case study presented, we intend to discuss the problematic of plastic surgery as a form of correction of traumatic lesions and whether or not its availability should be taken into account during clinical assessment.

\section{Case Study}

In this case, we studied an 18 year old, female student, victim of a car accident in 01-04-2001. She suffered dislocation of the right shoulder, bifocal fractures of the right humerus (figs. 1, 2 and 3) and pelvis (fig. 4), second degree burn of the left thigh (fig. 5) and generalized abrasions throughout the body. The fractures of the arm were surgically treated, whilst the ones of the pelvis were treated conservatively. 
As for the lesions on the thigh, the patient was submitted to a skin graft, derived from the ipsilateral leg, which then formed a queloid (figs. 5, 6, 7 and 8).

One year later, two expandable prostheses were placed beneath the healthy skin of the left thigh and were periodically filled, consequently increasing the amount of normal skin (figs. 9, 10 and 11).

They were then removed and the scared segment was excised, leaving a much narrower scar on the external aspect of the knee and lower thigh. The scar was surgically revised two more times measuring in the end, $25 \mathrm{~cm}$ longitudinally per $5 \mathrm{~cm}$ in its widest portion (figs 12, 13 and 14).

In the end, aesthetic damage was evaluated as 4 in a scale of 7 degrees, of increasing severity.

\section{Discussion and Conclusion}

When observed by the medico-legal expert, the patient had by far, a more discreet scar then initially, a fact that positively influenced the end result of the evaluation. Taking this example into consideration, two main questions arise. Firstly concerning the time elapsed between the traumatic event and the moment of observation. It is essential, for final conclusions, that the sequels are considered consolidated before examination. And secondly, one could be tempted to argue that in all cases, in which cosmetic surgery intervention could be of assistance in the resolution or minimization of the deformities produced by the traumatic event, it should be compulsory for the patients to accept such treatment. However, like any other form of medical management, it involves specific risks and each individual is entitled to determine which therapeutics presented should or not be accepted.

Therefore, would it be reasonable to slightly devaluate the sequels presented in cases of refusal of further cosmetic treatment?

Due to its controversy, it was concluded that it depends on each individual evaluator to determine whether in any given case, it would be reasonable to slightly devaluate the sequels presented when the patient refuses further cosmetic treatment at disposal.

\section{References}

ARGUEDAS M.A Reflexiones médico legales acerca del perjuicio estético, Med. Leg. Costa Rica; 19(1):67-7312, 2002.

FRANCHITTO N. et al. Review Medicolegal evaluation of aesthetic impairment: Particularities of post-burn scars, 2008.

VIEIRA D.N. e QUINTERO J.A. Aspectos práticos da avaliação do dano corporal em Direito Civil, 7:85-96, 2008. 


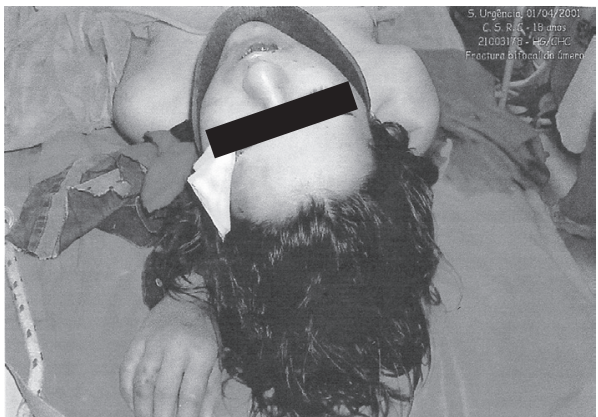

Figure 1 - Patient in the emergency room

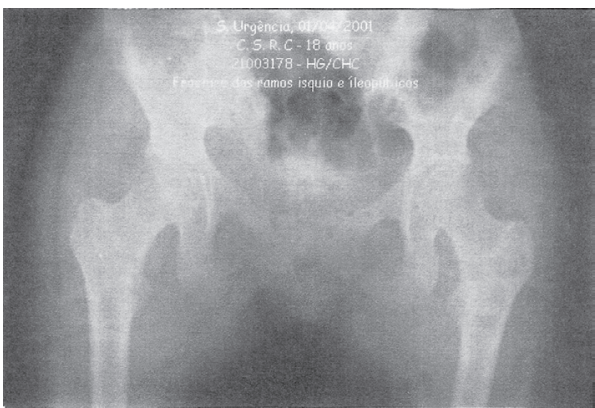

Figure 3 - X-ray of the fractured pelvis

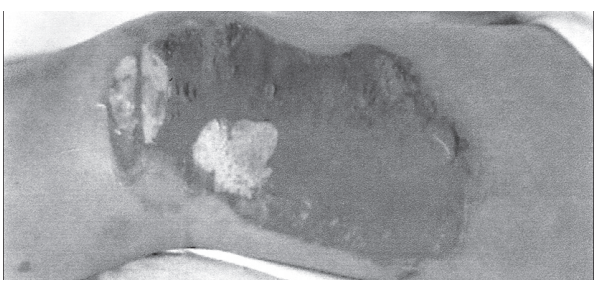

Figure 5 - Close view of the second degree burn of the left thigh

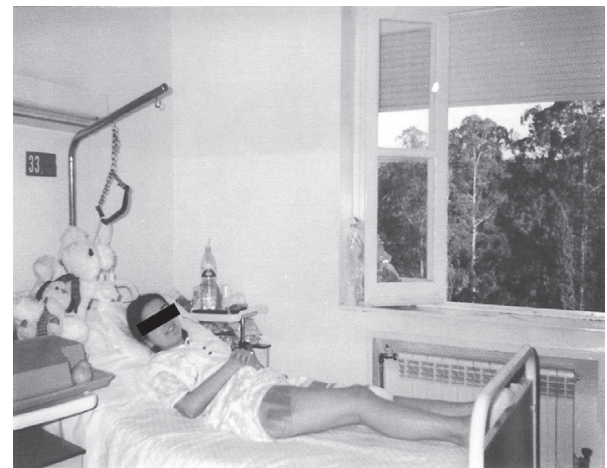

Figure 6 - Donor region of the skin graft on the right thigh.

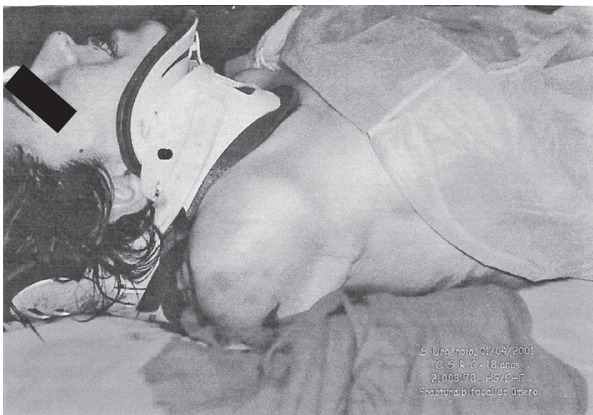

Figure 2 - Closer view of the dislocation of the shoulder in the emergency room

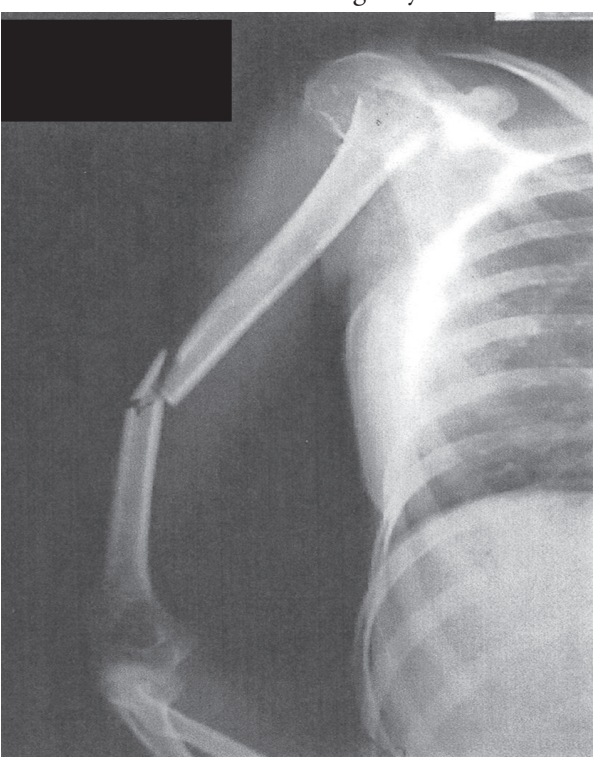

Figure 4 - X-ray revealing the bifocal fracture of the right humerus

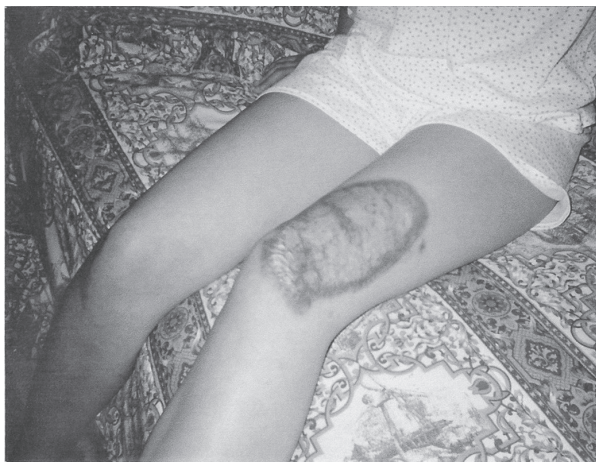

Figure 7- Healing of the lesion after the receiving the skin graft 


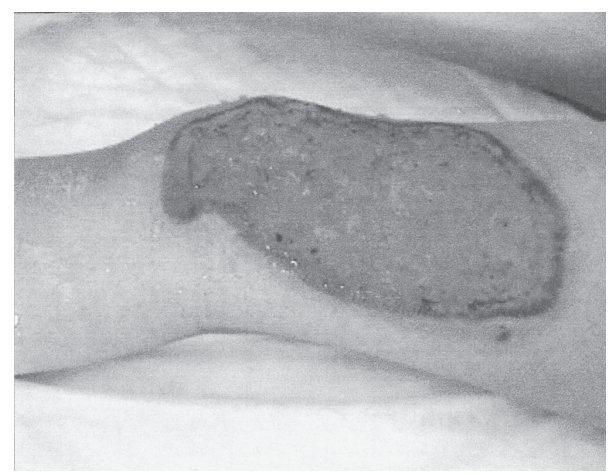

Figure 8 - Closer view of the healing tissue

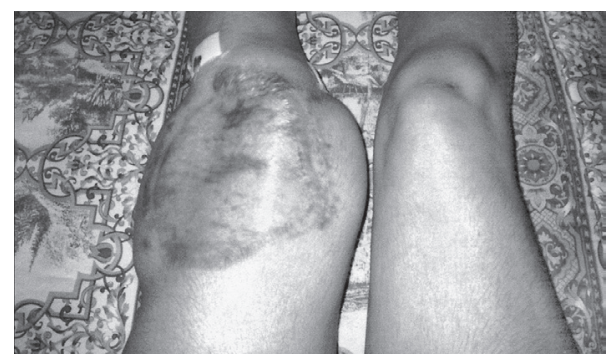

Figure 10 - Expandable prostheses fuller than before, increasing the amount of normal skin

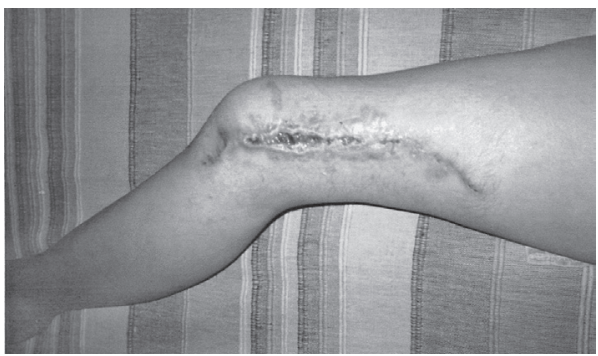

Figure 12 - Scar after the first corrective surgery

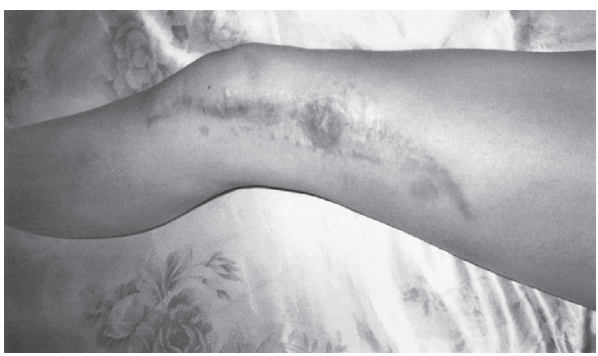

Figure 14 - Final result after plastic surgery intervention

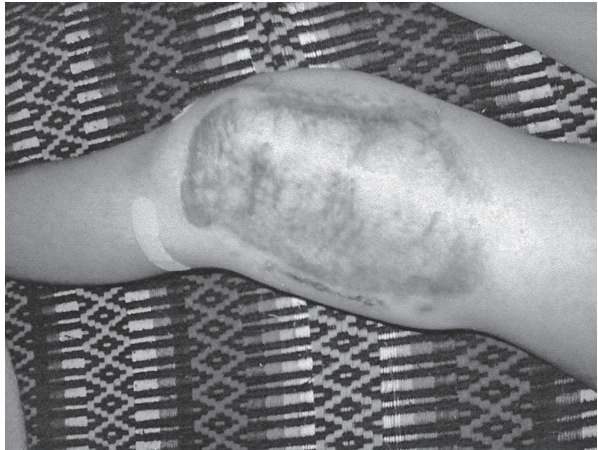

Figure 9 - View of the expandable prostheses placed beneath the healthy skin

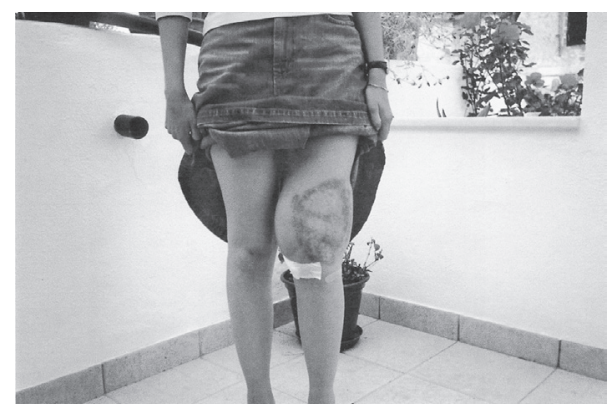

Figure 11 - Prostheses at maximum volume

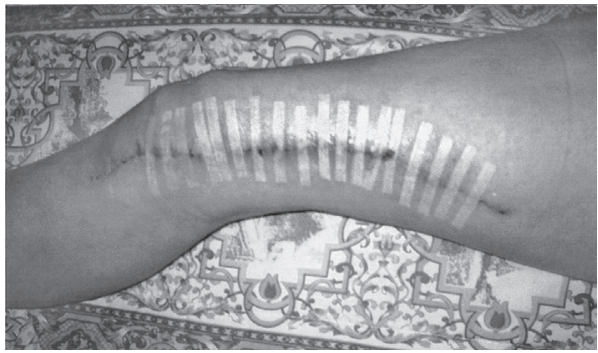

Figure 13 - Status after the second corrective surgery 